\title{
Impelementasi Asuhan Keperawatan Dalam Proses Perencanaan \\ Keperawatan
}

\section{Riana Silvia Casuarina L.Tobing}

\section{riana.sct@gmail.com}

\section{Latar Belakang :}

Proses Keperawatan adalah suatu metode yang sistematis dan terorganisasi dalam pemberian asuhan keperawatan, yang difokuskan pada reaksi dan respons unik individu pada suatu kelompok atau perorangan terhadap gangguan kesehatan yang dialami, baik actual maupun potensia. Potter \& Perry (2005) menjelaskan tujuan dari proses keperawatan adalah mengidentifikasi kebutuhan perawatan kesehatan klien, menentukan prioritas, memberikan intervensi keperawatan yang dirancang untuk memenuhi kebutuhan klien, dan mengevaluasi keefektifan asuhan keperawatan dalam mencapai hasil dan tujuan klien yang diharapkan.Perencanaan keperawatan adalah rencana tindakan keperawatan yang dilakukan oleh perawat kepada klien dengan tujuan untuk mecapai kesejahteraan kesehatan klien dan kemandirian klien menjaga kesehatannya, Pada tahap ini perawat membuat rencana tindakan keperawatan untuk mengatasi masalah dan meningkatkan kesehatan klien, yang dimana kita ketahui perencanaan keperawatan adalah salah satu bagian dari asuhan keperawatan,yang terbagi atas pengkajian keperawatan,diagnosa keperawatan, perencanaan keperawatan,implementasi keperawatan,dan evaluasi keperawatan. Implementasi keperawatan adalah serangkaian kegiatan yang dilakukan oleh perawat untuk membantu pasien dari masalah status kesehatan yang dihadapi kestatus kesehatan yang baik yang menggambarkan kriteria hasil yang diharapkan. Proses pelaksanaan implementasi harus berpusat kepada kebutuhan klien, faktor-faktor lain yang mempengaruhi kebutuhan keperawatan, strategi implementasi keperawatan, dan kegiatan komunikasi. Tahap proses keperawatan dgn melaksanakan berbagai strategi tindakan keperawatan yg telah direncanakan, Perawat harus mengetahui berbagai hal seperti bahaya fisik, perlindungan perlindungan pasien, teknik komunikasi, prosedur tindakan. 


\section{Tujuan :}

Untuk mengetahui dan memahami Pengertian dan Proses Impelementasi Asuhan keperawatan Dalam Proses Perencanaan Keperawatan.

\section{Metode :}

Metode yang digunakan dalam kajian ini adalah metode pengumpulan data dari beberapa artikel jurnal penelitian yang dipublikasi pada basis elektronik menggunakan metode tersearch dan analisis dari berbagai sumber seperti buku teks, referensi jurnal, dan e-book, dengan menggunakan Google Scholar,Portal Garuda dan Jurnal Keperawatan Indonesia. Yang berhubungan dengan Proses Impelementasi Asuhan Keperawatan Dalam Proses Perencanaan Keperawatan.

\section{Hasil:}

Dengan adanya standar keperawatan dalam memberikan asuhan keperawatan ke pasien diharapkan perawat mempunyai patokan atau pedoman dalam memberikan layanan kesehatan, sehingga tidak terjadi tumpang tindih antara profesi yang satu dengan yang lain, dan tidak sampai terjadi mal praktek. pengetahuan mengenai pelaksanaan implementasi keperawatan bagi klien di rumah sakit mengungkapkan kembali tugas dan tanggungjawab seorang perawat dalam membuat suatu implementasi keperawatan yang efektif sesuai dengan diagnosa yang telah ditetapkan sebelumnya sehingga profesi perawat dapat melaksanakan tugasnya berdasarkan pengetahuan yang mendalam dengan profesional. Implementasi serangkaian kegiatan yang dilakukan oleh perawat berdasarkan tindakan yang telah di rencanakan pada tahap intervensi. Berdasarkan terminologi NIC, implementasi terdiri atas melakukan dan mendokumentasikan tindakan yang merupakan tindakan keperawatan khusus yang diperlukan untuk melaksanakan intervensi (atau program keperawatan). Perawat melaksanakan atau mendelegasikan tindakan keperawatan untuk intervensi yangg disusun dalam tahap perencanaan dan kemudian mengakhiri tahap implementasi dengan mencatat tindakan keperawatan dan respons klien terhadap tindakan tersebut. Adapun proses pada implementasi. 
1) Mengkaji kembali klien

2) Menentukan kebutuhan perawatan terhadap bantuan

3) Mengimplementasikan intervensi keperawatan

4) Melakukan supervisi terhadap asuhan yang didelegasikan

5) Mendokumentasikan tindakan keperawatan

Perawat mengimplementasikan intervensi yang didentifikasi dari rencana keperawatan. Kriteria pengukuran :

1) Intervensi bersifat konsisten dengan rencana perawatan yang dibuat.

2) Intervensi diimplementasikan dengan cara yang aman dan tepat.

3) Intervensi didokumentasikan.

\section{Pembahasan :}

Peran perawat sebagai pemberi asuhan merupakan komponen penting yang esensial dalam sistem pemberian pelayanan kesehatan. Kemampuan dan keterampilan perawat yang kuat dalam kepemimpinan dan administratif sangat penting bagi pasien dan keselamatannya serta sistem layanan dan aksesnya. Mutu asuhan yang unggul dapat memenuhi kebutuhan masyarakat terhadap kesehatan. Tuntutan tersebut membuat perawat perlu dipersiapkan dengan baik untuk membuat dan memelopori strategi perubahan dan mengelola secara efektif koordinasi dan integrasi dari tim interdisipliner, kebutuhan masyarakat, dan sistem asuhan yang berkelanjutan (Rabelo et al., 2016). Itulah sebabnya, integrasi asuhan keperawatan dan manajemen keperawatan menjadi salah satu inti kompetensi yang dibutuhkan perawat untuk menjalankan peran dan fungsinya dalam lingkungan layanan asuhan kesehatan. Asuhan keperawatan merupakan proses sistematis, terstruktur, dan integratif dalam badan keilmuan keperawatan. Asuhan ini diberikan melalui metode yang disebut proses keperawatan. Proses keperawatan yang didasari teori Orlando Deliberative Nursing Process menyatakan bahwa tindakan atau perilaku yang ditunjukkan perawat merupakan hasil pertimbangan berdasarkan kebutuhan pasien. Hal tersebut berarti bahwa perawat profesional melakukan eksplorasi kebutuhan dan masalah atau gangguan kebutuhan yang terjadi pada pasien dengan menggunakan persepsi, proses 
berpikir kritis, penalaran klinis, dan atau perasaan perawat yang berhubungan dengan kebutuhan dasar pasien. Proses keperawatan terdiri dari lima tahapan, yaitu pengkajian, diagnosis, perencanaan, implementasi, dan evaluasi. Implementasi yang merupakan komponen dari proses keperawatan adalah kategori dari perilaku keperawatan dimana tindakan yang diperlukan untuk mencapai tujuan dan hasil yang diperkirakan dari asuhan keperawatan yang dilakukan dan diselesaikan. Implementasi keperawatan adalah serangkaian kegiatan yang dilakukan oleh perawat untuk membantu klien dari masalah status kesehatan yang dihadapi kestatus kesehatan yang baik yang menggambarkan kriteria hasil yang diharapkan (Gordon, 1994, dalam Potter \& Perry, 1997). Ukuran intervensi keperawatan yang diberikan kepada klien terkait dengan dukungan, pengobatan, tindakan untuk memperbaiki kondisi, pendidikan untuk klien-keluarga, atau tindakan untuk mencegah masalah kesehatan yang muncul dikemudian hari. Untuk kesuksesan pelaksanaan implementasi keperawatan maka perawat harus mempunyai kemampuan kognitif (intelektual), kemampuan dalam hubungan interpersonal, dan keterampilan dalam melakukan tindakan. Proses pelaksanaan implementasi harus berpusat kepada kebutuhan klien, faktor-faktor lain yang mempengaruhi kebutuhan keperawatan, strategi implementasi keperawatan, dan kegiatan komunikasi.

\section{Adapun tujuan imlementasi keperawatan adalah sebagai berikut:}

a) Melaksanakan hasil dari rencana keperawatan untuk selanjutnya di evaluasi untuk mengetahui kondisi kesehatan pasien dalam periode yang singkat

b) Mempertahankan daya tahan tubuh klien

c) Mencegah terjadinya komplikasi

d) Menemukan perubahan system tubuh

e) Memberikan lingkungan yang nyaman bagi klien.

f) Menyesuaikan dengan impementasi dokter. 


\section{Jenis Implementasi Keperawatan}

Dalam pelaksanaannya terdapat tiga jenis implementasi keperawatan, yaitu:

1. Independent Implementations Adalah implementasi yang diprakarsai sendiri oleh perawat untuk membantu pasien dalam mengatasi masalahnya sesuai dengan kebutuhan, misalnya: membantu dalam memenuhi activity daily living (ADL), memberikan perawatan diri, mengatur posisi tidur menciptakan lingkungan yang terapeutik, memberikan dorongan motivasi, pemenuhan kebutuhan psiko-sosiokultural, dan lain-lain.

2. Interdependen/Collaborative Implementations Adalah tindakan keperawatan atas dasar kerjasama sesama tim keperawatan atau dengan tim kesehatan lainnya, seperti dokter. Contohnya dalam hal pemberian obat oral, obat injeksi, infus, kateter urin, naso gastric tube (NGT), dan lain-lain.

3. Dependent Implementations Adalah tindakan keperawatan atas dasar rujukan dari profesi lain, seperti ahli gizi, physiotherapies, psikolog dan sebagainya, misalnya dalam hal: pemberian nutrisi pada pasien sesuai dengan diit yang telah dibuat oleh ahli gizi, latihan fisik (mobilisasi fisik) sesuai dengan anjuran dari bagian fisioterapi.

\section{Prinsip Implementasi Keperawatan}

Beberapa pedoman atau prinsip dalam pelaksanaan implementasi keperawatan adalah sebagai berikut:

1. Berdasarkan respons pasien

2. Berdasarkan ilmu pengetahuan, hasil penelitian keperawatan, standar pelayanan profesional, hukum dan kode etik keperawatan

3. Berdasarkan penggunaan sumber-sumber yang tersedia

4. Sesuai dengan tanggung jawab dan tanggung gugat profesi keperawatan

5. Mengerti dengan jelas pesanan-pesanan yang ada dalam rencana intervensi keperawatan 
6. Harus dapat menciptakan adaptasi dengan pasien sebagai individu dalam upaya meningkatkan peran serta untuk merawat diri sendiri (self care)

7. Menekankan pada aspek pencegahan dan upaya peningkatan status kesehatan.

8. Menjaga rasa aman, harga diri dan melindungi pasien

9. Memberikan pendidikan, dukungan dan bantuan

10. Bersifat holistik

11. Kerjasama dengan profesi lain

12. Melakukan dokumentasi

\section{Metode impementasi keperawatan yaitu:}

1. Membantu dalam aktifitas kehidupan sehari-sehari, Aktifitas kehidupan sehari-hari adalah aktifitas yang biasanya dilakukan dalam sepanjang hari normal: mencakup ambulasi, makan, berpakaian, menyikat gigi, berhias.

2. Konseling adalah metode implementasi yang mebantu klien menggunakan proses pemecahan masalah untuk mengenali dan menangani stres dan yang memudahkan hubungan interpersonal antara klien, keluarganya, dan tim perawatan kesehatan. Ini berjtujuan untuk membantu klien menerima perubahan yang akaan terjadi yang diakibatkan stres berupa dukungan emosional, intelektual, spiritual, dan psikologis.

3. Penyuluhan adalah metode implementasi yang digunakan untuk menyajiakn prinnsip, prosedur, dan teknik yang tepat tentang perawatn kesehatan untuk klien dan untuk menginformasikan klien tentang status kesehatannya.

4. Memberikan asuhan keperawatan langsung.

5. Kompensasi untuk reaksi yang merugikan.

6. Teknik tepat dalam memberikan perawatan dan menyiapkan klien untuk prosedur.

7. Mencapai tujuan perawatan.

8. Mengawasi dan mengevaluasi kerja dari anggota staf lain 


\section{Tahap pelaksanaan implementasi keperawatan secara langsung pada klien}

A. Tahap pelaksanaan

- Mengkomunikasikan/ menginformasikan kepada klien tentang keputusan tindakam keperawatan yang dilakukan oleh perawat.

- Beri kesempatan kepada klien untuk mengekspresikan perasaannya terhadap penjelasan yang telah diberika oleh perawat.

- Mererapkan pengetahuan intelektual, kemampuan hubungan antar manusia dan kemampuan teknis keperawatan dalam tindakan pelaksanaan keperawatan yang diberikan oleh perawat.

- Hal-hal yang perlu diperhatikan pada saat pelaksanaan tindakan adalah energi klien, pencegahan kecelakaan dan komplikasi, rasa aman, privacy, kondisi klien, respon klien terhadap tindakan yang telah diberikan.

B. Tahap terminasi

- Terus memperhatikan respon klien terhadap tindakan keperawatan yang telah diberikan.

- Tinjau kemajuan klien dari tindakan keperawatan yang telah diberikan.

- Rapikan peralatan dan lingkungan klien dan lakukan terminasi

- Lakukan pendokumentasian.

\section{Penutup:}

Keperawatan suatu bentuk pelayanan dibidang kesehatan yang didasari ilmu dan kiat keperawatan yang ditujukan kepada individu, keluarga, masyarakt baik yang sakit maupun yang sehat sejak lahir sampai meninggal. Kegiatan pelayanan meliputi upaya peningkatan kesehatan, pencegahan penyakit, pemulihan serta pemeliharaan kesehatan sesuai dengan wewenang, tanggung jawab serta etika . bentuk pelayanan profesional berupa pemenuhan kebutuhan dasar yang diberikan kepada individu yang sehat maupun sakit yang mengalami gangguan fisik, psikis, dan sosial agar dapat mencapai derajat kesehatan yang optimal. Bentuk pemenuhan kebutuhan dasar dapat berupa meningkatkan kemampuanyang ada pada individu, mencegah, memperbaiki, dan melakukan rehabilitasi dari suatu 
keadaan yang dipersepsikan sakit oleh individu. Mutu pelayanan keperawatan yang merupakan hasil kegiatan asuhan keperawatan adalah terjaminnya penerapan standar asuhan keperawatan yang dilakukan oleh perawat berdasarkan pendekatan proses keperawatan, yang meliputi pengkajian data, diagnosa keperawatan, rencana keperawatan, tindakan dan evaluasi dengan Perencanaan keperawatan yang memiliki tahap pada proses keperawatan yang dilakukan setelah penegakan Diagnosa Keperawatan Perencanaan keperawatan adalah suatu rangkaian kegiatan penentuan langkah-langkah pemecahan masalah dan prioritasnya, perumusan tujuan, rencana tindakan dan penilaian asuhan keperawatan pda pasien/klien berdasarkan analisis data dan diagnosa keperawatan. perencanaan keperawatan sangat penting untuk mencapai kesehatan klien dan kesejahteraan klien. Pendekatan jaminan mutu layanan keperawatan mengutamakan keluaran (outcome) layanan keperawatan atau apa yang akan dihasilkan dan diakibatkan oleh layanan keperawatan. Hasil layanan keperawatan yang bermutu hanya mungkin dihasilkan oleh pekerjaan yang benar. Dengan demikian, klien akan selalu berada dalam lingkungan organisasi layanan keperawatan dengan mutu yang terbaik sebagai salah satu hal yang terkait yaitu Implementasi keperawatan merupakan langkah nyata yang dilakukan perawat pada klien untuk melaksanakan rencana perawatan yang telah dirancang untuk menangani masalah klien seperti memberikan rasa nyaman,menjamin kesehatan klien dan mencegah terjadinya kompilkasi serta menyesuaikan implementasi yang dilakukan perawat. 


\section{DAFTAR PUSTAKA}

Butar-Butar, J., \& Simamora, R. H. (2016). Hubungan Mutu Pelayanan Keperawatan dengan Tingkat Kepuasan Pasien Rawat Inap di RSUD Pandan Kabupaten Tapanuli Tengah. Jurnal Ners Indonesia, 6(1), 50-63.

Dinarti., Mulyanti, Y. (2017). Dokumen Keperawatan. Jakarta: Kementerian Kesehatan Republik Indonesia.

Fatie, M., Felle, Z. R. (2018). Hubungan Tingkat Pendidikan Perawat dan Penerapan Kompetensi Pendokumentasian Proses Keperawatan. Jurnal Keperawatan Tropis Papua,1(21), 21-24.

Koerniawan, D., Daeli, N.E., \& Srimiyanti. (2020). Aplikasi Standart Proses Keperawatan: Diagnosa, Outcome, Dan Intervensi Pada Asuhan Keperawatan. Jurnal keperawatan Silampari, 3(2),739-751.

Kusnadi, E. (2017). Analisis Kelengkapan Dokumwntasi Keperawatan Di Ruang Rawat Inap Non Intensive Rumah Sakit X. Jurnal Bidang Ilmu Kesehatan, 9(1), 553-562.

Purwanto, E. (2012). Impelementasi dan Evaluasi Keperawatan. Universitas Muhammdiyah Malang.

Rezky. (2018). Gambaran Faktor Yang Mempengaruhi Pelaksanaan Asuhan Keperawatan Individu Di Puskesmas Kota Makassar. Skripsi FKEP UNHAS Makassar.

Saubari, A.N., Wahyudin., \& Machi, R .(2018). Impelementasi Rencana Startegi Pelayanan Keperawatan Dalam Persepktif Kepemimpinan Kepala Ruangan Berbasis Budaya Organisasi Di Rumah Sakit. Caring Nursing Jurnal, 2(2), 51-59.

Simamora, R. H. (2005). Hubungan Persepsi Perawat Pelaksana Terhadap Penerapan Fungsi Pengorganisasian Yang Dilakukan Oleh Kepala Ruangan Dengan Kinerjanya Diruang Rawat Inap RSUD Koja Jakarta Utara (Doctoral dissertation, Tesis FIK UI, Tidak dipublikasikan).

Sumilat, N. P. (2017). Standart Pendokumentasian Asuhan Keperawatan Di BIUD RSUD Kota Baubau. Skripsi FKIP UIN Alauddin Makassar. 
Tarigam, R., Handayani, H. (2019). Manfaat Implementasi Dokumentasi Asuhan Keperawatan Berbasis Komputerisasi Dalam Meningkatkan Mutu Asuhan Keperawatan. Jurnal Ilmiah Kesehatan pencerah,8(2), 110-116.

Tokan, P. K., Sekunda, M.S. (2020). Penerapam Format Baru Pendokumentasian Asuhan Keperawatan Di Poli Rawat Jalan Puskesmas. Jurnal Kesehatan Primer,5(1), 61-69. 